\title{
Análise das funções comunicativas expressas por terapeutas e pacientes do espectro autístico****
}

\author{
Analyses of the communicative functions expressed by language \\ therapists and patients of the autistic spectrum
}

\author{
Liliane Perroud Miilher * \\ Fernanda Dreux Miranda Fernandes **
}

\author{
* Fonoaudióloga. Mestranda em \\ Ciências da Reabilitação - \\ Comunicação Humana - Universidade \\ de São Paulo. Endereço para \\ correspondência: Rua Ibraim Habib, 51 \\ - Osasco - SP. CEP 06040-400 \\ (li_miilher@hotmail.com). \\ **Fonoaudióloga. Professora Livre \\ Docente do Departamento de \\ Fisioterapia, Fonoaudiologia e Terapia \\ Ocupacional da Faculdade de Medicina \\ da Universidade de São Paulo. \\ ***Trabalho Realizado no \\ Departamento de Fisioterapia, \\ Fonoaudiologia e Terapia Ocupacional \\ da Faculdade de Medicina da \\ Universidade de São Paulo. Pesquisa \\ Financiada pela Fundação do \\ Desenvolvimento Administrativo do \\ Estado de São Paulo (FUNDAP).
}

\section{Artigo de Pesquisa}

Artigo Submetido a Avaliação por Pares

Conflito de Interesse: não

Recebido em 28.11.2005.

Revisado em 11.09.2006; 09.11.2006.

Aceito para Publicação em 09.11.2006.

\begin{abstract}
Background: communicative functions used by language therapists and patients. Aim: to analyze the communicative functions used by language therapists and patients of the autistic spectrum. Method: the communicative functions expressed by six therapists in interaction with six patients each were analyzed, constituting 36 profiles of communicative functions expressed by the dyad therapist-patient. All therapists were part of a Training Program in Childhood Psychiatric Disorders and the patients were diagnosed within the autistic spectrum. Data were gathered using the transcriptions of a videotaped therapy session and these were analyzed according to the criteria suggested by Fernandes (2000). The communicative functions were divided in two different ways: interpersonal and non-interpersonal, and instrumental, regulatory, interactive, personal, heuristic and imaginative. Results: the comparison between the functions used by the language therapists and the patients indicated a statistically significant difference in use of the following functions: request of social routine, request of information, request of action, comment, recognition of other, exclamation, non-focused, exploratory, exhibition, play and reactive. There was also a statistically significant difference between the use of interpersonal, non-interpersonal, regulatory, interactive, personal and heuristic communicative functions. Conclusion: the functional communicative profile of language therapists is different from the one presented by their patients when comparing each communicative function and when the communicative functions are grouped (interpersonal and non-interpersonal, and instrumental, regulatory, interactive, personal, heuristic and imaginative). Therapists use communicative functions to fill in the communicative space and to make requests. This finding agrees with the findings of previous studies.
\end{abstract}

Key Words: Pragmatics; Communication; Autism.

\section{Resumo}

Tema: funções comunicativas utilizadas por terapeutas e pacientes. Objetivo: analisar o uso de funções comunicativas por terapeutas de pacientes do espectro autístico. Método: Foram analisadas as funções comunicativas utilizadas por seis terapeutas em interação com seis pacientes cada, constituindo um corpo de análise de 36 perfis de funções comunicativas por díade terapeuta-paciente. Todas as terapeutas faziam parte do Programa de Aprimoramento em Distúrbios Psiquiátricos da Infância, seus pacientes pertenciam ao espectro autístico. Para a coleta dos dados foram utilizadas as transcrições da gravação de uma sessão de terapia e analisadas segundo Fernandes, (2000). As funções comunicativas foram divididas de duas formas: mais e menos interpessoais e instrumental, regulatória, interacional, pessoal, heurística e imaginativa . Resultados: a comparação entre as funções usadas por terapeutas e paciente revelou que houve diferença estatisticamente significante no uso das funções: pedido de rotina social, de informação e de ação, comentário, reconhecimento do outro, exclamativa, não focalizada, exploratória, exibição, jogo e reativa. Quanto à divisão em funções mais e menos interpessoais ou entre funções instrumental, regulatória, interacional, pessoal, heurística e imaginativa houve diferença estatisticamente significante no uso das funções mais e menos interpessoais e das funções regulatória, interacional, pessoal e heurística. Conclusão: o perfil funcional da comunicação das terapeutas é bastante distinto do de seus pacientes quando comparamos cada uma das funções e quando analisamos os agrupamentos de funções (mais e menos interpessoais e instrumental, regulatória, interacional, pessoal, heurística e imaginativa). As terapeutas utilizam funções para preencher o espaço comunicativo e realizar pedidos, resultado que concorda com estudos anteriores.

Palavras-Chave: Pragmática; Comunicação; Autismo.

Referenciar este material como:

MIILHER, L. P.; FERNANDES, F. D. M. Analyses of the communicative functions expressed by language therapists and patients of the autistic spectrum (original title: $\checkmark$ Análise das funções comunicativas expressas por terapeutas e pacientes do espectro autístico). Pró-Fono Revista de Atualização Científica, Barueri (SP), v. 18, n. 3, $\sum 3$ p.239-248, set.-dez. 2006. 


\section{Introduction}

Language development has been the theme of discussions and focus of different research fields. There are questions about intervening factors to this process and some researchers consider cognitive and social issues as pre-requisites and while others consider these as areas affected by language. Even without a rigid position, the question about the interdependency between social, cognitive and linguistic aspects still exists (Molini-Avejonas and Fernandes, 2004).

This interrelation is not only true to typical development but also to disorders that occur during infancy. Some of the most intriguing of them are the ones associated to the autistic spectrum. The first scientific description of this population was made by Kanner in 1943 and since then several researchers were dedicated to studying it. Among the different research lines and explanations about the causes of autism the description of linguistic characteristics remains as one of the central features (Fernandes, 2000a). In several studies it is clear that the relation between cognitive, social and linguistic aspects is fundamental to the full comprehension of the autistic spectrum whose distinctive feature is the marked impairment in social interaction.

The first affective bond in normal development is determined with the adult responsible by the child's care. As the bearer of culture he/she will be the child's guide to the world and will be the first to associate meaning to initially noncommunicative vocalizations (Borges and Salomão, 2000; Sperry and Symons, 2003).

This role of first communicative partner becames even more important when we focus joint attention. This ability, precociously acquired in normal development, presupposes that the child is willing to communicate his/her desire to the other through eye-gaze of the use of gestures (Jones and Carr, 2004). Affective exchanges occurring during adult-child interaction related to other referent (object or event) function as the basis to verbal communication which, by its turn, contributes to the improvement of the child's socialcognitive abilities (Bosa e Callias, 2000). Studies that focus these abilities in children with autism are unanimous stating that these children present deficits in the acquisition and development of joint attention.

Parents, the first communicative partners, adjust their speech to the child aiming to facilitate communication. Therefore, the parent's communicative behavior can be an important facilitator to the child's communicative development (Siller and Sigman, 2002; Sperry and Symons, 2003). Siller and Sigman (2002) state that autistic children's parents synchronize their behavior to the child's attention focus, as the parents of children with typical development or with delayed development. They proposed the hypothesis that parents' communicative stile evolved from the impression they have about their child's communicative abilities. The tuning between child and parents was also observed by Newland and colleagues (2001). The authors observed that as the child gets older and linguistically more competent the dyad engages in more complex play, thus suggesting that there is a connection between social play and the emergence of language.

The relation between language and play in mother-child dyads was also analyzed in respect to the context provided by the mother to the child's language development and about the stimulus to the use of words and gestures to communicate. Williams (2003) stated that children with autism engaged in more individual and exploratory activities than normally developing children during play situations with their parents and that they use fewer joint attention gestures to share topics of interest with the communicative partner.

Loveland and colleagues (1988) observed that parents of children with autism tend to initiate more communication episodes and to use more imperative phrases than the parents of normally developing children.

The focus on the interpreter's role played by parents and care takers leads to the notion of specularity. It is evidenced by the dependence between adult and child on the dialog, that is, the adult is dialogically dependent on the child and vice-versa (Borges and Salomão, 2000).

In a study about the use of a software to improve linguistic abilities of children with autism and other developmental disorders Tjus and colleagues (2001) pointed out that there was a correlation between the behaviors expressed by the teacher and by the child. The more passive was the child the more directive the teacher became. Besides, they observed that there is a relation between the child's linguistic abilities and the teacher's communication.

Cervone and Fernandes (2005) found that there was a balance in the number of communicative acts 
expressed per minute during interaction between adults and children of 4 and 5 years. They also detected a significant difference related to the children's age.

During social interaction interlocutors consolidate their communicative competence. This competence presents a close relation to the improvement of sensibility about the listener and the conditions in which the speech acts are considered appropriate or not. Besides phonological and syntactic learning the child learns the social rules that govern the interaction with the communicative partner. The cognitive and social pre-requisites, the language functions, the conversational rules and stylistic variations are learning during social interaction, essential to the language acquisition processes (prutting, 1982).

Studies have shown that individuals of the autistic spectrum present communicative intent (Molini and Fernandes, 2003) and are sensitive to the communicative partner (Bernard-Optiz, 1982). This author studied the interference of different interlocutors in the communication of children with autism. The results showed that these children used more communicative functions when interacting with a familiar adult (mother or clinician) than with a non-familiar adult. Analyzing the adult's communication it was observed that they used more requests than any other function.

Frequently the studies about language acquisition and development in autism place their focus on the child's communication (Fernandes and Barros, 2001; Molini amd Fernandes, 2003; Cardoso and Fernandes, 2003). Some of them analyzed the mother-child dyad aiming to understand how the roles of parents and care-takers influence the autistic child's communication (Borges and Salomão, 2000; Siller and Sigman, 2002).

The contribution of these studies is undeniable but little attention has been placed on the language therapist's role, what can be confirmed by the absence of studies on international data bases. The therapist's action, although not systematically studied, becomes more relevant when early intervention is considered (Diehl, 2003).

The therapeutic focus evolved from behavioral motivations and considerations to an approach that emphasizes the pragmatic aspects of language (Molini and Fernandes, 2003). One of the major criticisms about behavioral practices is the lack of transference of learned abilities to every-day-life situations. That is, there is no generalization of the trained issues to situations of natural interaction.
It leaded researchers and clinicians to search for more natural therapeutic procedures that aimed not only language abilities but also interactive competences, considering the interlocutor also (Beisler and Tsai, 1983). Some studies focused on therapeutic efficiency measured according to standard criteria but not directly focusing the therapists’ action (law and Garret, 2004).

Some directions as: symmetry between therapist and patient; realistic positions regarding communication, where misunderstandings are part of the communicative process and not something to be avoided and consistency regarding communicative functions and means are considered important aspects of the therapists' procedures with children of the autistic spectrum (Fernandes, 2003).

Most of the therapeutic approaches aim the development of functional speech and use some techniques to achieve it: increasing motivation, use of directive reinforcements, variations of concrete stimulus, reinforcement of verbal communicative attempts, use of multiple examples and others (Koegel et al., 1987). Despite considering some issues about the interlocutor the main objective is the increase in the number of spoken words, without addressing other aspects as the use of other communicative means and different communicative contexts. Koegel (2000) pointed out that the intervention processes have focused on increasing spontaneity, varying communicative functions, using language socially and other questions.

Increasing social interaction has been the focus of some studies (McConnel, 2002). According to the author researches have different approaches: ecological variations, intervention on collateral abilities, specific intervention with the child, peer (of the same age) mediated intervention and comprehensive intervention (all approaches are included). Although these researches provide information about the therapist's role they don't specifically analyze it, but their guiding principles.

In the literature few studies (Bernard-Optiz, 1982; Fernandes, 2000a) focus on the therapistchild rapport although this dyad is always considered potentially important to the prognosis of the child of the autistic spectrum. Fernandes (2000a) studied the functional aspects of the communication of children with autism in the context of language therapy. Functions used by children and therapists were compared. Results indicate that adults used requests (of information and action) to communicate and interact with the child. To occupy the communicative space 
comments and performatives were used and to obtain the child's attention the function of "showing off" was used. The proportion of requests was $44,8 \%$, comments and performatives were $22.5 \%$ and showing off were $18.5 \%$. Requests were also used by the therapists studied by Bernard-Optiz (1982).

The analysis of the communication of therapist and patient is necessary to the reflection about the clinical practice. This way the general aim of this research was to study the pragmatic profile of therapists of children of the autistic spectrum.

Specific objectives were:

. identify the communicative functions expressed by therapists and patients, according to the criteria proposed by Cardoso and Fernandes (2003);

. identify the communicative functions expressed by therapistis and patients, according to the criteria proposed by Halliday (1978);

. compare communicative functions expressed by different therapists.

\section{Method}

Subjects

Participants of this study were six language therapists of individuals with diagnosis within the autistic spectrum. The therapists were enrolled on a professional specialization practice program on a specialized laboratory of the School of Medicine - University of Sao Paulo. They were recently graduated, with ages varying between 21 and 26 years and were all female. Each of them had around 15 autistic patients enrolled in individual language therapy programs.

The data of six language therapy sessions of each therapist, with different patients were used, thus forming an analysis corpus of 36 adult-child pairs. Language therapy is based on the pragmatic psycho-linguistic framework. The average time of therapy of each child with each therapist, prior to the analyzed session, was 6 months.

All patients were diagnosed by psychiatrists according to the DSM-IV or the ICD-10, were attending language therapy in the same service for an average time of 18 months and their age varied between 5 and 16 years.

\section{Material}

30 minute language therapy sessions were video-taped according to the criteria approved by the institution's ethic committee (460/02). To each recording the toys preferred by each child were used. After recorded, the data were transcribed to a specific protocol and the 15 minutes with most symmetric interaction were analyzed about the functional communicative profile.

The functional communicative profile was determined according to the criteria suggested by Fernandes (2000b). The communicative functions considered were:

Object request - OR: Acts or utterances used to request a concrete desired object.

Action request $-\mathrm{AR}$ : Acts or utterances used to request that the other perform an action. Includes requests for help.

Social Routine Request - Acts or utterances used to request that the other initiate or continue a social interaction play. It is a specific kind of action request involving interaction.

Consent Request - CR: Acts or utterances used to request permission to perform an action. Involves an action.

Information - IR: Acts or utterances used to request for information about an object or an event. Include wh- question and other utterances with interrogative prosodic contour.

Protest - PR: Acts or utterances used to interrupt an action. Include opposing resistance to the action of other and rejecting offered object.

Recognition of Other - RO: Acts or utterances used to obtain attention of other or to indicate the recognition of the presence. Includes calling, compliments, topic and politeness markers.

Showing-Off - SO: Acts or utterances used to attract attention to self. The initial performance may be accidental and the child repeats it when notes it attracts attention.

Comment - C: Acts or utterances used to direct attention to an object or event. Include pointing, showing, describing, informing.

Self Regulatory - SR: Utterances used to verbally control owns action. Utterances may immediate precede or co-occur with motor behavior.

Labeling - L: Acts or utterances used to focus own attention on an object or event by referent identification.

Performative - PE: Acts or utterances used in familiar action schemes applied to objects. Include sound effects and ritualized vocalizations synchronically produced with motor behavior.

Exclamatory-EX: Acts or utterances expressing an emotional reaction to na event or situation. Includes expressions of surprise, pleasure, frustration and discontentment and immediately 
succeeds a significant event.

Reactive - RE: Utterances produced while examining or interacting with an object or body part. There is no evidence of communicative intent, but the subject is focusing attention to object or body part and seam to be reacting to it. It may serve to self-stimulatory functions.

Non-focused - NF: Acts or utterances produced although the subject's attention is not focused any object or person. There is no evidence of communicative intent.

Play - P: Acts involving organized activity, but self centered; includes primary circular reactions.

Exploratory - XP: Acts involving activities of investigating a determined object or body part or clothes.

Narrative - NA: Utterances aimed to narrate real or imaginary facts. There may be attention by the listener or not.

Protest Expression - PE: Crying, whining, tantrums or other protest manifestation not necessarily directed toward a person, event or object.

Joint Play - JP: Organized activity shared between adult and child.

Procedure

The occurrence of each communicative function used by patients and therapists was analyzed. Functions were divided as interpersonal functions (OR, AR, IR, CR, SR, C, RO, PR, EP, NA, JP, SO e EX) and non-interpersonal functions (RE, NF, SR, P, XP, PE e L) according to the suggestion presented by Cardoso and Fernandes (2003).

Functions were also classified according to Hallyday’s (1978) suggestion: instrumental, regulatory, interaction, personal, heuristic and imaginative. The first category (instrumental) included the PR, PE, EX, SR, PE and P functions. Regulatory functions were OR, AR, SR and CR. Interaction functions were $\mathrm{C}, \mathrm{N}, \mathrm{JP}$ and $\mathrm{RO}$. Personal functions were SO, RE and NF. The functions IR and XP were considered heuristic and NA was considered imaginative.
Data analysis

Data were statistically analyzed using the tstudent test with significance level of 5\% (0.050) to identify the difference between averages. To compare the performance of different therapists the ANOVA (Analysis of Variance) was used.

\section{Results}

Table 1 presents the total results (all therapists compared to all patients). It presents that the mean values, the standard deviation and the significance level of each analyzed function. P value was determined by the t-student test for paired data. Numerical values (indicate total amount) are related to the number of communicative acts and the percentile values are related to the occupation of the communicative space.

The results of function groups' analysis are presented on Table 2. It can be observed that only the functions classified as instrumental and imaginative didn't present statistical significant results.

The comparison between therapists with regard to the total number of communicative functions is presented on Table 3. The different variables (patient and therapist) indicate two different ways of analyzing data. In both cases the analysis focus the therapist and it can be seen by the functions expressed by the patient and by the therapist. Statistical analysis used the analysis of variance (ANOVA) and significance value was determined at 0.050 .

The comparative analysis between therapists, regarding the use of interpersonal and noninterpersonal communicative functions, is presented on Table 4. It can be observed that all comparisons were statistically significant showing a qualitative difference on the functional use of communication.

The comparative analysis of the six therapists regarding the use of the instrumental, regulatory, interactive, personal, heuristic and imaginative functions can be observed in Table 5. Only the instrumental and interactive functions presented statistically significant results when the therapists' communicative profiles were considered. 
TABLE 1. Analysis of numerical and percentile average of each communicative function used by therapists and patients.

\begin{tabular}{|c|c|c|c|c|c|c|c|c|c|c|}
\hline & \multicolumn{5}{|c|}{ Numerical value } & \multicolumn{5}{|c|}{ Percentile value } \\
\hline & \multicolumn{2}{|c|}{ Patient } & \multicolumn{3}{|c|}{ Therapist } & \multicolumn{2}{|c|}{ Patient } & \multicolumn{3}{|c|}{ Therapist } \\
\hline & Average & $\begin{array}{l}\text { Standard } \\
\text { deviation }\end{array}$ & p-value & Average & $\begin{array}{c}\text { Standard } \\
\text { deviation }\end{array}$ & Average & $\begin{array}{l}\text { Standard } \\
\text { deviation }\end{array}$ & $\mathrm{p}$-value & Average & $\begin{array}{l}\text { Standard } \\
\text { deviation }\end{array}$ \\
\hline OR & 1,36 & 1,71 & 0,073 & ,83 & ,97 & 2,37 & 3,31 & $0.012^{*}$ & ,93 & 1,09 \\
\hline SR & ,36 & 1,10 & $0.021 *$ & 1,22 & 1,76 & ,57 & 2,04 & 0.085 & 1,42 & 1,93 \\
\hline IR & 2,19 & 4,31 & $<0.001^{*}$ & 20,72 & 15,06 & 2,96 & 5,21 & $<0.001^{*}$ & 21,34 & 10,77 \\
\hline RO & 3,64 & 4,20 & $0.003 *$ & 1,53 & 1,81 & 5,24 & 5,58 & $0.001^{*}$ & 1,99 & 2,63 \\
\hline $\mathrm{C}$ & 6,64 & 9,76 & $<0.001^{*}$ & 23,75 & 9,92 & 8,94 & 11,80 & $<0.001 *$ & 27,25 & 10,37 \\
\hline $\mathrm{N}$ & 1,56 & 3,85 & 0.804 & 1,44 & 2,90 & 1,99 & 4,21 & 0.222 & 1,25 & 2,25 \\
\hline EX & 1,36 & 4,15 & $0.015^{*}$ & 2,83 & 3,40 & 1,61 & 4,83 & 0.072 & 2,79 & 3,35 \\
\hline $\mathrm{NF}$ & 9,44 & 10,27 & $<0.001^{*}$ & ,00 & ,00 & 15,77 & 19,27 & $<0.001^{*}$ & ,00 & ,00 \\
\hline $\mathrm{XP}$ & 8,06 & 6,67 & $<0.001 *$ & ,33 & ,79 & 13,75 & 12,91 & $<0.001^{*}$ & ,34 & ,83 \\
\hline $\mathrm{PE}$ & 2,33 & 3,57 & 0.316 & 1,72 & 2,37 & 3,94 & 6,07 & 0.059 & 1,95 & 2,74 \\
\hline AR & 4,89 & 7,61 & $<0.001^{*}$ & 14,94 & 7,63 & 6,80 & 8,79 & $<0.001^{*}$ & 16,27 & 7,04 \\
\hline CR &, 56 & 1,92 & 0.318 & 1,00 & 1,55 & 1,28 & 5,02 & 0.780 & 1,03 & 1,47 \\
\hline $\mathrm{PR}$ & 1,83 & 3,88 & 0.720 & 2,06 & 2,68 & 3,06 & 6,08 & 0.390 & 2,20 & 2,80 \\
\hline SO & 2,58 & 5,24 & $0.001 *$ & 6,83 & 8,42 & 3,95 & 7,95 & $0.012^{*}$ & 7,26 & 7,95 \\
\hline SR & ,53 & 2,21 & 0.161 & ,00 & ,00 & ,64 & 2,32 & 0.107 & ,00 & ,00 \\
\hline $\mathrm{PE}$ & 9,44 & 7,37 & 0.843 & 9,19 & 6,60 & 16,03 & 13,28 & 0.050 & 11,44 & 8,66 \\
\hline $\mathrm{JP}$ & 1,53 & 2,41 & 0.091 & 1,17 & 1,81 & 2,88 & 5,37 & $0.013^{*}$ & 1,34 & 2,59 \\
\hline $\mathrm{P}$ & 2,36 & 3,37 & $0.010 *$ & ,72 & 1,65 & 3,83 & 5,81 & $0.005^{*}$ & ,76 & 1,71 \\
\hline NA & ,19 & 1,01 & 0.560 & ,36 & 1,42 & ,28 & 1,50 & 0.926 & ,25 & ,97 \\
\hline $\mathrm{RE}$ & 2,08 & 3,07 & $0.001 *$ & ,42 & ,81 & 3,36 & 5,01 & $0.001^{*}$ & ,45 & ,87 \\
\hline TOTAL & 62,94 & 25,02 & $<0.001^{*}$ & 91,08 & 27,00 & 40,31 & 8,05 & $<0.001^{*}$ & 59,96 & 8,33 \\
\hline
\end{tabular}

Legend: OR - object request; SR - social routine request; IR - information; RO - recognition of other; C - comment; L - labeling; EX exclamatory; NF- non-focused; XP- exploratory; PE- protest expression; AR- action request; CR- consent request; PR- protest; SOshowing-off; SR- self regulatory; PE - performative; JP - join play; P - play; NA - narrative; RE - reactive.

$* \mathrm{p}<0.05$ (T- Student test) 
TABLE 2. Analyzis of function groups used by therapists and patients.

\begin{tabular}{|c|c|c|c|}
\hline Variables & Average & Standard deviation & Significance (p) \\
\hline P_FNI & 33,47 & 15,74 & \multirow{2}{*}{$<0,001^{*}$} \\
\hline T_FNI & 12,11 & 7,25 & \\
\hline P_FI & 29,47 & 20,67 & \multirow[b]{2}{*}{$<0.001 *$} \\
\hline T_FI & 78,97 & 27,07 & \\
\hline P_Ins & 19,22 & 8,48 & \multirow{2}{*}{0.347} \\
\hline T_Ins & 17,75 & 7,28 & \\
\hline P_Reg & 5,81 & 7,90 & \multirow{2}{*}{$<0.001^{*}$} \\
\hline T_Reg & 17,17 & 8,36 & \\
\hline P_Int & 18,61 & 13,59 & \multirow[b]{2}{*}{$<0.001^{*}$} \\
\hline T_Int & 27,89 & 12,11 & \\
\hline P_Pes & 14,11 & 10,72 & \multirow[b]{2}{*}{$<0.001 *$} \\
\hline T_Pes & ,78 & 1,53 & \\
\hline P_Heu & 10,25 & 7,06 & \multirow{2}{*}{$<0.001 *$} \\
\hline T_Heu & 21,06 & 15,13 & \\
\hline P_Ima & 19 & 1,01 & \multirow{2}{*}{0.560} \\
\hline T_Ima & ,36 & 1,42 & \\
\hline
\end{tabular}

P - patient; T - therapist; NIF - non-interpersoal function; IF - interpersonal function; Ins - instrumental; Reg - regulatory; Int interactive; Pes - personal - Heu - heuristic; Ima - imaginative

$* \mathrm{p}<0.05$ (T- Student test )

TABLE 3. Comparative analysis of therapists regarding the total of communicative functions.

\begin{tabular}{|c|c|c|c|c|c|c|c|c|}
\hline \multirow[b]{2}{*}{ Variable } & \multirow[b]{2}{*}{ Therapist } & \multirow[b]{2}{*}{$\mathrm{n}$} & \multicolumn{3}{|c|}{ Numerical values } & \multicolumn{3}{|c|}{ Valores percentuais } \\
\hline & & & Average & Standard deviation & Significance & Average & Standard deviation & Significance \\
\hline \multirow{7}{*}{ Therapist } & 1 & 6 & 105,83 & 9,79 & \multirow{7}{*}{$0.038 *$} & 59,83 & 7,22 & \multirow{7}{*}{$0.007 *$} \\
\hline & 2 & 6 & 100,00 & 12,13 & & 67,83 & 7,00 & \\
\hline & 3 & 6 & 93,00 & 51,07 & & 65,83 & 5,12 & \\
\hline & 4 & 6 & 61,67 & 13,50 & & 54,82 & 8,69 & \\
\hline & 5 & 6 & 101,83 & 17,30 & & 54,33 & 5,50 & \\
\hline & 6 & 6 & 84,17 & 13,24 & & 57,13 & 7,60 & \\
\hline & Total & 36 & 91,08 & 27,00 & & 59,96 & 8,33 & \\
\hline
\end{tabular}

$* \mathrm{p}<0.05$ (ANOVA) 
TABLE 4. Comparative analysis of therapists' communication regarding the use of personal and non-interpersonal communicative functions.

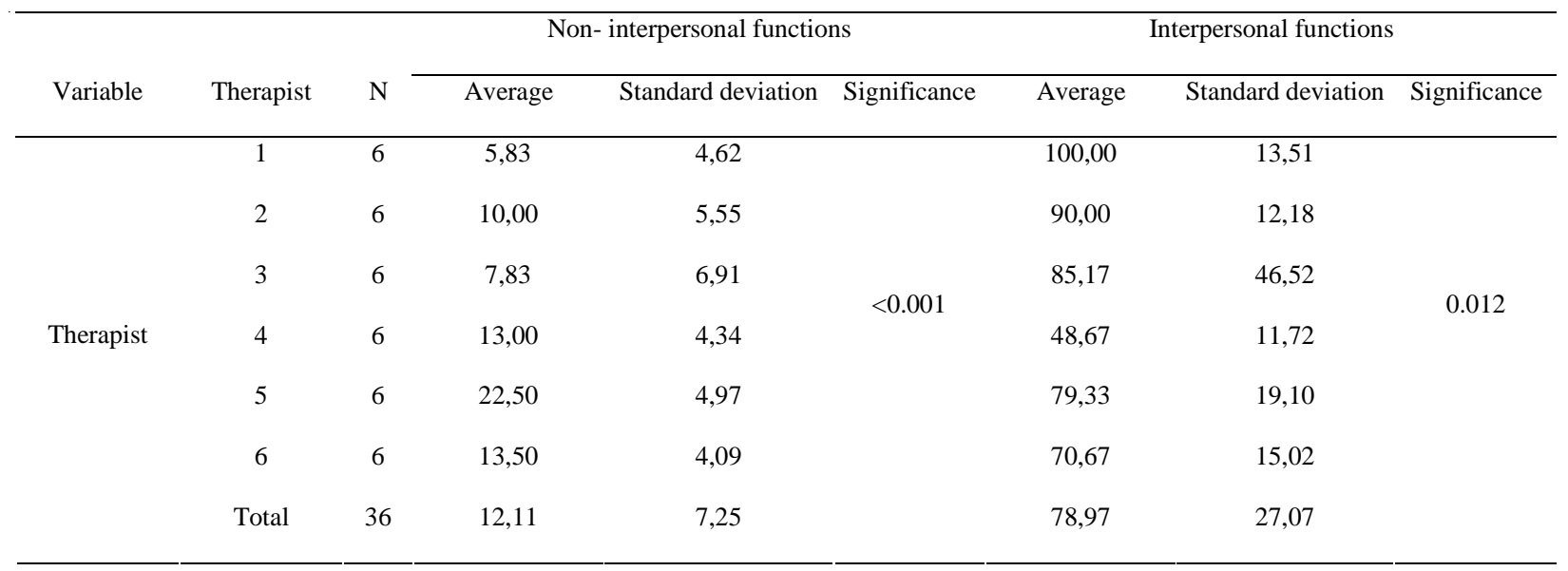

$\mathrm{n}$ - number of subjects

$* \mathrm{p}<0.05$ (ANOVA)

TABLE 5. Comparative analysis of the use of instrumental, regulatory, interactive, personal, heuristic and imaginative functions by the six therapists.

$\begin{array}{lllllll} & \text { Instrumental } & \text { Regulatory } & \text { Interactive } & \text { Personal } & \text { Heuristic } & \text { Imaginative } \\ \text { Average } & 17.75 & 17.17 & 27.89 & 0.78 & 21.06 & 0.36 \\ \begin{array}{l}\text { Standard deviation } \\ \text { Significance }\end{array} & 7.28 & 8.36 & 12.11 & 1.53 & 15.13 & 1.42 \\ * \mathrm{p}<0.05 \text { (ANOVA) } & 0.026 * & 0.053 & 0.001 * & 0.083 & 0.324 & 0.070\end{array}$

\section{Discussion}

The analysis of the functional communicative profile has shown that some communicative functions are used in the same way by therapists and patients alike. Some other functions are more frequently used either by the therapists or by the patients. Considering the similarity of the use of communicative functions it can be observed a kind of communicative balance on the therapist-patient relationship. The therapists tend to adapt his/her communication to the patient's, producing a more symmetric interaction (Fernandes, 2003) and sharing the patient's attention focus (Siller and Sigman, 2002).

However, this symmetry was not observed in all studied functions. It confirms that the therapeutic process with persons with autism demands a more intense and directive attitude, as can be observed by the use of the showing-off function. On the other hand, some functions used just by the patients are described as characteristic of autistic persons as the non-focused and exploratory functions (Williams, 2003).

In the functions object request and joint play, social routine request and exclamatory the statistical difference was detected on the numerical value or on the percentile values. In the first two functions (object request and joint play) the statistical difference was observed in the percentile values but not in the numerical ones indicating that these differences are related to the occupation of the communicative space. In the two last functions occurred the opposite: there was no 
statistically significant difference in the percentile values but it was observed in the numerical values. These results indicates that the analysis of number of communicative acts and communicative space should be used with different objectives.

The larger differences of performance were observed in the non-focused, exploratory, information request, comment and action request functions. Except for the non-focused and exploratory functions the therapists presented the largest averages. This result is different from the observed in children with typical development of 4 and 5 years that frequently used the comment function (Cervone and Fernandes, 2005).

The therapists used mostly the functions of comment, information request, action request, performative and showing-off. The first of these functions usually works as a link between reality and play and communicates the speaker's thoughts to the interlocutor. The request functions (on information and action) direct the child's behavior to the adult's demand and show the regulatory character of communication (BernardOptiz, 1982; Tjus et al., 2001). The use of showingoff function reveals that frequently the patients did not share the adult's attention focus, this way evidencing the sharing inability (Jones and Carr, 2004).

The performative function, considered noninterpersonal, was used as a play element. Considering that inabilities in imaginative functions are one of the characteristics of the autistic spectrum (American Psychiatric Association, 1995; Williams, 2003), this function was used to provide an interesting play environment. These results are similar to those described by Fernandes (2000a), that is, the most frequent functions were requests, comments, performatives and showing-off.

Grouping the functions as interpersonal and non-interpersonal and as instrumental, regulatory, interactive, personal, heuristic and imaginative showed that, despite they contribute to the identification of the communicative profile, they highlight the individual performance differences. In the groups instrumental and imaginative there were no statistically significant differences although the functions of the first group have an earlier development than the ones of the second, that requires higher levels of communicative competence (Prutting, 1982).

The comparison among therapists showed that, although they were interacting with patients with the same diagnosis and they all had specialized knowledge (Diehl, 2003), each one was distinct from the others. It happened not just when the functions were individually analyzed but also when they were considered as interpersonal and noninterpersonal and as instrumental and interactive. The use of non-interpersonal functions by the therapists shows that they can use communicative behaviors similar to those of the patients aiming to share their focus of attention and this way using environmental elements during therapy (McConnel, 2002).

As stated by Sperry and Symons (2003) in their research with parents of children with autism, the therapists involve their patients with interpersonal stimulus. It occurs because the therapists consider the patients' communicative acts less intentional and therefore offer them the opposite stimulus to bring them to the communicative situation.

\section{Conclusion}

The analysis of the use of communicative functions by therapists of patients of the autistic spectrum placed the focus on the therapist as a real interlocutor and a mediator in the therapeutic process. The similarities and differences observed show that communication is an individual construct and that interaction is a live phenomenon where partners present approximating and distancing points.

It was possible to identify the functions used by the therapists, grouping the functions according to the criteria proposed by Cardoso and Fernandes (2003) and Halliday (1978). The use of these criteria provided different ways of analysis about the therapist's communication.

Although the therapists were interacting with persons with the same diagnosis it didn't lead to homogeneous results, and it reinforces the interactive diversity. 


\section{References}

AMERICAN PSYCHIATRIC ASSOCIATION. Manual de diagnóstico e estatística de transtornos mentais - DSMIV. 4. ed. Porto Alegre: Artes Médicas, 1995.

BEISLER, J. M.; TSAI, L.Y. A pragmatic approach to increase expressive language skills in young autistic children. J. Autism Dev. Disord., New York, v. 13, n. 3, p. 287-303, sep. 1983.

BERNARD-OPTIZ, V. Pragmatic analysis of the communicative behavior of an autistic children. J. Speech Hear. Dis., Washington, v. 47, n. 1, p. 99-109, feb. 1982.

BORGES, L. C.; SALOMÃO, N. M. R. Aquisição de linguagem: considerações da perspectiva da interação social. Psicol. Reflex Crit., Porto Alegre, v. 16, n. 2, p. 327-336, maio-ago. 2003.

BOSA, C.; CALLIAS, M. Autismo: breve revisão de diferentes abordagens. Psicol. Reflex Crit., Porto Alegre, v. 13, n. 1, p. 167-177, jan.-abr. 2000.

CARDOSO, C.; FERNANDES, F. D. M. Uso de funções comunicativas interpessoais e não interpessoais em crianças do espectro autístico. Pró-Fono R. Atual. Cient., Barueri (SP), v. 15, n. 3, p. 279-286, 2003.

CERVONE, L. M.; FERnANDES, F. D. M. Análise do perfil comunicativo de crianças de 4 e 5 anos na interação com adulto. R. Soc. Bras. Fonoaudiol., São Paulo, v. 10, n. 2, p. 97-105, abr.-jun. 2005.

DIEHL, S. F. Autism spectrum disorder: the context of speech-language pathologist intervention. Lang. Speech Hear. Serv. Schools, Maryland, v. 34, n. 3, p. 177-179, jul. 2003.

KANNER, L. Autistic disturbances of affective contact. Nerv. Child, Baltimore, v. 2, p. 217-250, 1943.

FERNANDES, F. D. M. Aspectos funcionais da comunicação de crianças autistas. T. Desenv., São Paulo, v. 9, n. 51, p. 25-35, 2000a.

FERNANDES, F. D. M. Pragmática. In: ANDRADE, C. R. F.; BEFI-LOPES, D. M.; FERNANDES, F. D. M.; WERTZNER, H. F. ABFW: teste de linguagem infantil nas áreas de fonologia, vocabulário, fluência e pragmática. Carapicuiba (SP): Pró-Fono, 2000b. cap. 4, p. 77-89.

FERNANDES, F. D. M. Sugestões de procedimentos terapêuticos de linguagem em distúrbios do espectro autístico. In: LIMONGI, S. C. O. (Org.). Fonoaudiologia: informação para formação. Rio de Janeiro: Guanabara Koogan, 2003. p. 55-65.

FERNANDES, F. D. M.; BARROS, C. H. C. Funções comunicativas expressas por crianças autistas: o uso de procedimentos específicos para inseri-las no contexto da terapia de linguagem. J. Bras. Fonoaudiol., Curitiba, v. 2, n. 6, p. 45-54, jan.-mar. 2001.

HALLIDAY, M. Language as social semiotic: the social interpretation of language and meaning. Maryland: University Park Press, 1978.
JONES, E. A.; CARR, E. G. Joint attention in children with autism: theory and intervention. Focus Autism Other Dev. Disabil., Austin, v. 19, n. 1, p. 13-26, mar. 2004.

KOEGEL, R. L.; O'DELL, M. C.; KOEGEL, L. K. A natural language teaching paradigm for nonverbal autistic children. J. Autism Dev. Disord., New York, v. 17, n. 2, p. 187200, jun. 1987.

KOEGEL, L. K. Intervention to facilitate communication in autism. J. Autism Dev. Disord., New York, v. 30, n. 5, p. 383-391, oct. 2000.

LAW, J.; GARRET, Z. Speech and language therapy: its potential role in CAMHS. Child Adoles Menl Health, Oxford, v. 9, n. 2, p. 50-55, may 2004.

LOVELAND, K. A.; LANDRY, S. H.; HUGHES, S. O.; HALL, S. K.; McEVOY, R. E. Speech acts and the pragmatics deficits in autistic children. J. Speech Hear. Res., Washington, v. 47, p. 593-604, 1988.

McCONNEL, S. R. Interventions to facilitate social interaction for young children with autism: review of available research and recommendations for educational intervention and future research. J. Autism Dev. Disord., New York, v. 32, n. 5, p. 351-372, oct. 2002.

MOLINI, D. R.; FERNANDES, F. D. M. Intenção comunicativa e uso de instrumentos em crianças com distúrbios psiquiátricos. Pró-Fono R. Atual. Cient., Barueri (SP), v. 15, n. 2, p. 149-158, maio-ago. 2003.

MOLINI-AVEJONAS, D. R.; FERNANDES, F. D. M. Alterações pragmáticas, cognitivas e sociais em crianças com autismo: revisão de literatura. R. Soc. Bras. Fonoaudiol., São Paulo, v. 9, n. 3, p. 179-186, jul.-set. 2004.

NEWLAND, L. A.; ROGGMAN, L. A.; BOYCE, L. K. The development of social play and language in infancy. Infant Behav. Dev., Norwood, v. 24, n. 1, p. 1-25, jan. 2001.

PRUTTING, C. A. Pragmatic as social competence. J. Speech Hear. Dis., Washington, v. 47, p. 123-134, 1982.

SILLER, M.; SIGMAN, M. The behaviors of parents of children with autism predict the subsequent development of their children's communication. J. Autism Dev. Disord., New York, v. 32, n. 2, p. 77-89, apr. 2002.

SPERRY, L. A.; SYMONS, F. J. Maternal judgments of intentionality in young children with autism: the effects of diagnostic information and stereotyped behavior. J. Autism Dev. Disord., New York, v. 33, n. 3, p. 281-287, jun. 2003.

TJUS, T.; HEIMANN, M.; NELSON, K. E. Interaction patterns between children and their teachers when using a specific multi-media and communication strategy. Autism, London, v. 5, n. 2, p. 175-187, jun. 2001.

WILLIAMS, E. A comparative review of early forms of object-directed play and parent-infant play in typical infants and young children with autism. Autism, London, v. 7, n. 4, p. 361-377, dec. 2003. 